\title{
Clinical and immunogenetic characteristics of European multicase rheumatoid arthritis families
}

Rheumatology Unit, University Hospital La Paz, 28046 Madrid, Spain

A Balsa

D Pascual-Salcedo

University Hospital, $6500 \mathrm{HB}$ Nijmegen, The Netherlands

P Barrera

T R D J Radstake

Katholieke Universiteit Leuven, 3212

Pellenberg, Belgium

$\mathrm{R}$ Westhovens

K Maenaut

M Spaepen

Hospital S Joao, 4200 Porto, Portugal

$\mathrm{H}$ Alves

G de Almeida

A Lopes-Vaz

Hôpital Lariboisiere, 75010 Paris, France

F Cornélis

T Bardin

P Fritz

Généthon, 91002 Evry,

France

F Cornélis

J F Prudhomme

P Fritz

Instituto de Patologia Medica, 56126 Pisa,

Italy

L Riente

P Migliorini

Laboratoire d'Histocompatibilité, Hospital Saint-Louis, 75010 Paris, France

V Lepage

D Charron

National Tissue Typing Centre, 11527 Athens,

Greece

C Stravopoulos

Institut National de la Santé et de la

Recherche Médicale

E06, 75010 Paris,

France

M Martinez

Correspondence to:

Dr A Balsa, Rheumatology

Unit, University Hospital La

Paz, Paseo de la Castellana,

261, 28046 Madrid, Spain

abalsa@hulp.insalud.es

Accepted 3 October 2000

^See appendix

Note: the first two authors contributed equally to the

writing of this paper.

A Balsa, P Barrera, R Westhovens, H Alves, K Maenaut, D Pascual-Salcedo, F Cornélis, T Bardin, L Riente, T R D J Radstake, G de Almeida, V Lepage, C Stravopoulos, M Spaepen, A Lopes-Vaz, D Charron, M Martinez, J F Prudhomme, P Migliorini, P Fritz, for the European Consortium on Rheumatoid Arthritis Families (ECRAF) ${ }^{\star}$

\section{Abstract}

Objective-To describe the characteristics of a new set of European families with affected sib pairs (ASP) collected by the European Consortium on Rheumatoid Arthritis Families (ECRAF) to replicate the results of our first genome scan. Potential gradients for disease severity in Europe and concordance within families were studied.

Patients and methods-From 1996 to 1998 European white families with at least two affected siblings were enrolled in the study. Demographic (sex, age at onset), clinical data (rheumatoid factor (RF), disease duration, erosive disease, extraarticular features (EF)), and HLA-DRB1 oligotyping were analysed.

Results-565 patients with rheumatoid arthritis (RA), belonging to 271 families including 319 affected sib pairs (ASP) were collected. Belgium, France, Italy, the Netherlands, Portugal, and Spain contributed 20, 96, 52, 24, 9, and 70 families, respectively. Sex ( $78 \%$ women), age at onset (mean 44 years), and RF positivity $(79 \%)$ were similar among the countries. Differences were found in disease duration (11-18 years) and in the prevalence of erosive disease (70-93\%), nodules (1544\%), subjective Sjögren's syndrome (5$38 \%)$, and EF $(3-16 \%) \quad(p<0.05$ in all cases). A total of $22 \%$ RA sibs were shared epitope (SE) negative, whereas $47 \%$ and $30 \%$ carried one and two SE alleles respectively. Carriage of SE differed widely among countries $(p<0.0001)$ : no SE alleles $(6-36 \%)$, one allele $(43-60 \%)$, and two alleles (20-39\%). SE encoding alleles were mainly DRB1*04 in the Netherlands and Belgium, whereas SE carriage was less common and evenly distributed between DRB $1{ }^{\star} 01,{ }^{\star} 04$, and ${ }^{\star} 10$ in Mediterranean countries. No concordance within families was found either in age/calendar year of onset (intraclass correlation coefficient $<0.50$ ) or in clinical and radiological features $(\kappa<0.22)$.

Conclusions-The differences in RA characteristics between European countries and within families underline the heterogeneity of the disease. No clear cut gradient of disease severity was seen in Europe.

(Ann Rheum Dis 2001;60:573-576)
Rheumatoid arthritis (RA) is a complex multigenic disease characterised by persistent symmetrical synovitis, leading to cartilage and bone destruction. Its cause is not known, but both genetic and environmental factors play a part. Evidence for the genetic contribution to the susceptibility for RA comes from the familial clustering of the disease, ${ }^{12}$ and from studies showing a four- to fivefold increased RA prevalence in monozygotic compared with dizygotic twins. $^{13}$

RA susceptibility is associated with certain class II genes in the major histocompatibility complex encoding for HLA-DR molecules. The HLA genes associated with RA encode a conserved amino acid sequence in the third hypervariable region of the DR $\beta$ chain referred to as the shared epitope (SE). ${ }^{4}$ This association shows ethnic and geographical variations. ${ }^{5} \mathrm{RA}$ is strongly associated with $\mathrm{DRB} 1^{\star} 0401$, ${ }^{\star} 0404$, and ${ }^{\star} 0408$ alleles in northern Europe, ${ }^{67}$ whereas in Greece, Spain, and Italy associations with $\mathrm{DRB} 1{ }^{\star} 0405,{ }^{\star} 0101,{ }^{\star} 0102$, and ${ }^{\star} 1001$ alleles have been shown. ${ }^{58-11}$

HLA class II genes have been estimated to explain only one third of the total genetic contribution to the disease. ${ }^{12}{ }^{13}$ The search for additional susceptibility loci in RA and other multigenic diseases has been stimulated by recent advances in molecular biology and automated gene scanning technology. Two basic approaches are being used at present: $(a)$ exclusion mapping using genome-wide scans and large panels of highly polymorphic microsatellites to identify non-random segregation of parental haplotypes between affected sibling pairs (ASP) $)^{14-16}$ and $(b)$ testing for potential candidate genes relevant for disease susceptibility. ${ }^{17}$

The European Consortium on Rheumatoid Arthritis Families (ECRAF) has performed an initial genome scan on 97 ASP families, which suggested a second RA locus on chromosome 3 and disclosed at least 10 other regions of interest containing new potential RA susceptibility loci. ${ }^{14}$ These results need to be replicated in additional sets of families. In this paper we describe the demographic and clinical characteristics of a large new set of ASP families collected by the ECRAF for such replication studies. Potential gradients for RA severity in Europe and concordance within families of disease characteristics were assessed in this family set. 
Table 1 Demographic, clinical, and immunogenetic characteristics of the patients studied. Data expressed as mean (SD) or percentage as indicated

\begin{tabular}{|c|c|c|c|c|c|c|c|c|}
\hline & $\begin{array}{l}\text { Belgium } \\
(n=43)\end{array}$ & $\begin{array}{l}\text { France } \\
(n=199)\end{array}$ & $\begin{array}{l}\text { Italy } \\
(n=107)\end{array}$ & $\begin{array}{l}\text { Netherlands } \\
(n=51)\end{array}$ & $\begin{array}{l}\text { Portugal } \\
(n=20)\end{array}$ & $\begin{array}{l}\text { Spain } \\
(n=144)\end{array}$ & p Value & $\begin{array}{l}\text { Total } \\
(n=564)\end{array}$ \\
\hline Families with sibsips (n) & 20 & 96 & 52 & 24 & 9 & 70 & & 271 \\
\hline Age at onset (years) & $\begin{array}{l}41(13) \\
(\mathrm{n}=43)\end{array}$ & $\begin{array}{l}44(14) \\
(\mathrm{n}=163)\end{array}$ & $\begin{array}{l}45(12) \\
(\mathrm{n}=102)\end{array}$ & $\begin{array}{l}47(13) \\
(\mathrm{n}=49)\end{array}$ & $\begin{array}{l}42(14) \\
(\mathrm{n}=20)\end{array}$ & $\begin{array}{l}45(12) \\
(\mathrm{n}=142)\end{array}$ & NS & $\begin{array}{l}44(13) \\
(\mathrm{n}=519)\end{array}$ \\
\hline Calendar year of disease onset & $\begin{array}{l}1979(11) \\
(\mathrm{n}=43)\end{array}$ & $\begin{array}{l}1979(11) \\
(\mathrm{n}=165)\end{array}$ & $\begin{array}{l}1983(10) \\
(\mathrm{n}=102)\end{array}$ & $\begin{array}{l}1985(8) \\
(\mathrm{n}=49)\end{array}$ & $\begin{array}{l}1981(8) \\
(\mathrm{n}=20)\end{array}$ & $\begin{array}{l}1984(10) \\
(\mathrm{n}=142)\end{array}$ & 0.0001 & $\begin{array}{l}1982(10) \\
(\mathrm{n}=521)\end{array}$ \\
\hline Disease duration (years) & $\begin{array}{l}18(12) \\
(\mathrm{n}=43)\end{array}$ & $\begin{array}{l}16(12) \\
(\mathrm{n}=163)\end{array}$ & $\begin{array}{l}13(10) \\
(\mathrm{n}=102)\end{array}$ & $\begin{array}{l}11(8) \\
(n=49)\end{array}$ & $\begin{array}{l}12(6) \\
(\mathrm{n}=20)\end{array}$ & $\begin{array}{l}13(10) \\
(\mathrm{n}=142)\end{array}$ & 0.001 & $\begin{array}{l}14(11) \\
(\mathrm{n}=519)\end{array}$ \\
\hline Female sex $(\%)$ & $\begin{array}{l}36(84) \\
(\mathrm{n}=43)\end{array}$ & $\begin{array}{l}150(75) \\
(\mathrm{n}=199)\end{array}$ & $\begin{array}{l}89(83) \\
(\mathrm{n}=107)\end{array}$ & $\begin{array}{l}34(68) \\
(n=51)\end{array}$ & $\begin{array}{l}14(82) \\
(\mathrm{n}=17)\end{array}$ & $\begin{array}{l}116(81) \\
(144)\end{array}$ & NS & $\begin{array}{l}439(78) \\
(n=564)\end{array}$ \\
\hline Rheumatoid factor positive (\%) & $\begin{array}{l}37(86) \\
(n=43)\end{array}$ & $\begin{array}{l}129(76) \\
(n=170)\end{array}$ & $\begin{array}{l}76(72) \\
(\mathrm{n}=105)\end{array}$ & $\begin{array}{l}38(79) \\
(\mathrm{n}=48)\end{array}$ & $\begin{array}{l}16(80) \\
(n=20)\end{array}$ & $\begin{array}{l}123(86) \\
(n=143)\end{array}$ & NS & $\begin{array}{l}419(79) \\
(n=529)\end{array}$ \\
\hline Nodules (\%) & $\begin{array}{l}19(44) \\
(\mathrm{n}=43)\end{array}$ & $\begin{array}{l}30(19) \\
(\mathrm{n}=161)\end{array}$ & $\begin{array}{l}28(27) \\
(n=103)\end{array}$ & $\begin{array}{l}19(40) \\
(\mathrm{n}=48)\end{array}$ & $\begin{array}{l}3(15) \\
(n=20)\end{array}$ & $\begin{array}{l}37(26) \\
(n=143)\end{array}$ & 0.0001 & $\begin{array}{l}136(26) \\
(n=518)\end{array}$ \\
\hline Subjective Sjögren's syndrome (\%) & $\begin{array}{l}14(33) \\
(\mathrm{n}=43)\end{array}$ & $\begin{array}{l}25(15) \\
(\mathrm{n}=165)\end{array}$ & $\begin{array}{l}19(18) \\
(\mathrm{n}=104)\end{array}$ & $\begin{array}{l}17(35) \\
(\mathrm{n}=48)\end{array}$ & $\begin{array}{l}1(5) \\
(n=20)\end{array}$ & $\begin{array}{l}54(38) \\
(\mathrm{n}=143)\end{array}$ & 0.004 & $\begin{array}{l}130(25) \\
(n=523)\end{array}$ \\
\hline Other extra-articular features $(\%)$ & $\begin{array}{l}7(16) \\
(\mathrm{n}=43)\end{array}$ & $\begin{array}{l}6(4) \\
(\mathrm{n}=166)\end{array}$ & $\begin{array}{l}15(14) \\
(\mathrm{n}=104)\end{array}$ & $\begin{array}{l}2(4) \\
(\mathrm{n}=49)\end{array}$ & $\begin{array}{l}1(5) \\
(n=20)\end{array}$ & $\begin{array}{l}4(3) \\
(\mathrm{n}=143)\end{array}$ & 0.0001 & $\begin{array}{l}35(7) \\
(\mathrm{n}=525)\end{array}$ \\
\hline Erosive disease $(\%)$ & $\begin{array}{l}40(93) \\
(\mathrm{n}=43)\end{array}$ & $\begin{array}{l}142(83) \\
(\mathrm{n}=171)\end{array}$ & $\begin{array}{l}71(70) \\
(\mathrm{n}=102)\end{array}$ & $\begin{array}{l}38(78) \\
(\mathrm{n}=49)\end{array}$ & $\begin{array}{l}16(84) \\
(\mathrm{n}=19)\end{array}$ & $\begin{array}{l}111(90) \\
(n=123)\end{array}$ & 0.0001 & $\begin{array}{l}418(83) \\
(n=519)\end{array}$ \\
\hline \multicolumn{9}{|l|}{ Shared epitope status (\%) } \\
\hline$-1-$ & $5(12)$ & $41(21)$ & $39(36)$ & $3(6)$ & $4(20)$ & $34(24)$ & 0.0001 & $126(22.3)$ \\
\hline$-1+$ & $26(60)$ & $91(46)$ & $46(43)$ & $28(55)$ & $10(50)$ & $66(46)$ & 0.0001 & $267(47.3)$ \\
\hline$+1+$ & $12(28)$ & $67(34)$ & $21(20)$ & $20(39)$ & $6(30)$ & $44(31)$ & 0.0001 & $170(30.1)$ \\
\hline
\end{tabular}

Patients and methods

From 1996 to 1998 European white ASP families were gathered in Belgium, France, Italy, the Netherlands, Portugal, and Spain. Candidate families, identified either by attending rheumatologists or self reported after media announcements, had to have at least two siblings fulfilling American College of Rheumatology criteria for RA. ${ }^{18}$ The diagnosis was confirmed by one of the rheumatologists participating in the study or by the clinician in charge of the patient.

A database was constructed using clinical and epidemiological data obtained from medical records and radiographs and/or from direct interviews and examination of patients, if needed. The variables studied included sex, age and calendar year at onset, disease duration, rheumatoid factor (RF) status, and presence/absence of erosive disease, nodules, subjective Sjögren's syndrome, and other extra-articular features (EF), including pericarditis, vasculitis, rheumatoid lung, or mononeuritis. HLA-DRB1 oligotyping was performed by polymerase chain reaction based methods.

\section{STATISTICAL ANALYSIS}

Differences among countries were assessed by analysis of variance and $\chi^{2}$ test for continuous and categorical variables, respectively. Concordance within families was analysed using a paired Student's $t$ test and intraclass correlation coefficient for continuous variables and a $\kappa$ test for categorical variables, respectively. In families with more than two affected sibs, a single random ASP was studied to avoid bias towards a greater concordance.

\section{Results}

Two hundred and seventy one European ASP families encompassing 565 patients with RA and 267 non-affected sibs were recruited by the ECRAF between 1996 and 1998 (table 1). The distribution of families (and affected sibs) by country was as follows: Belgium 20 (43), France 96 (199), Italy 52 (107), Netherlands
24 (51), Portugal 9 (20), and Spain 70 (144). Most families $(n=250)$ had only two affected sibs, but 19 families had three and two families had four affected sibs.

Table 1 shows demographic and clinical characteristics of the patients in the study. Age of onset, sex, and RF positivity were similar among the European countries. None the less we found differences in calendar year of disease onset (later onset in Spain and the Netherlands than in France; $F=0.0001$ ), disease duration (longer in Belgium and France than in the Netherlands; F=0.001). Significant differences between countries were also found in the prevalence of erosive disease ( $p=0.0001 ;>90 \%$ in Belgium and Spain), nodules ( $\mathrm{p}=0.0001$; $>40 \%$ in Belgium and the Netherlands), subjective Sjögren's syndrome $(p=0.004$; $>30 \%$ in Spain, the Netherlands, and Belgium), and extra-articular features $(\mathrm{p}=0.0001$; $>10 \%$ in Belgium and Italy). Despite these differences, no clear cut geographical gradient in clinical, biological, or radiological manifestations between northern and southern Europe was seen.

Tables 1 and 2 show the distribution of HLA-DRB1 alleles encoding the SE. A total of $47 \%$ and $30 \%$ of the patients carried a single and double SE allele respectively, whereas $22 \%$ of the RA sibs were SE negative.

Large differences in SE carriage and in the distribution of alleles were seen among the countries $(p=0.0001)$. SE negative patients were more rare in the Netherlands and Belgium ( $6 \%$ and $12 \%$, respectively) than in Mediterranean countries and Portugal (20$36 \%)$. Altogether, HLA-DRB1 ${ }^{\star} 0401$ and 0101 alleles were most prevalent $(41 \%$ and $22 \%$ respectively) and ${ }^{\star} 0405,{ }^{\star} 0408$, and ${ }^{\star} 0102$ less frequent $(<8 \%)$. In the Netherlands and Belgium SE encoding alleles were predominantly $\mathrm{DR}^{\star} 04$ (81\% and $88 \%$ respectively), whereas in the other countries the distribution in $\mathrm{DR}^{\star} 04,{ }^{\star} 01$, and ${ }^{\star} 10$ was more even. 
Table 2 Distribution of HLA-BRB1 alleles in ECRAF countries. Data expressed as number and percentage of alleles. For shared epitope (SE) as number and percentage of subjects

\begin{tabular}{|c|c|c|c|c|c|c|c|c|c|c|c|c|c|c|c|c|}
\hline & \multicolumn{2}{|c|}{${ }^{*} 0101$} & \multicolumn{2}{|c|}{${ }^{\star} 0102$} & \multicolumn{2}{|c|}{${ }^{*} 0401$} & \multicolumn{2}{|c|}{${ }^{\star} 0404$} & \multicolumn{2}{|c|}{${ }^{*} 0405$} & \multicolumn{2}{|c|}{${ }^{\star} 0408$} & \multicolumn{2}{|c|}{${ }^{\star} 1001$} & \multicolumn{2}{|c|}{ SE positive } \\
\hline & No & $\%$ & No & $\%$ & No & $\%$ & No & $\%$ & No & $\%$ & No & $\%$ & No & $\%$ & No & $\%$ \\
\hline Belgium & 5 & 10 & - & - & 32 & 64 & 8 & 16 & 2 & 4 & 2 & 4 & 1 & 2 & 38 & 88.4 \\
\hline France & 49 & 21.7 & 7 & 3.1 & 101 & 44.8 & 31 & 13.7 & 6 & 2.7 & 18 & 8 & 13 & 5.7 & 158 & 79.4 \\
\hline Italy & 27 & 30.7 & 2 & 2.3 & 13 & 14.8 & 19 & 21.6 & 10 & 11.4 & 1 & 1.1 & 16 & 18.2 & 68 & 63.5 \\
\hline Netherlands & 9 & 13.2 & - & - & 41 & 60.3 & 9 & 13.2 & - & - & 5 & 7.3 & 4 & 5.9 & 48 & 94 \\
\hline Portugal & 7 & 31.8 & - & - & 10 & 45.4 & - & - & - & - & 5 & 22.7 & - & - & 16 & 80 \\
\hline Spain & 34 & 22.1 & 13 & 8.4 & 49 & 31.8 & 12 & 7.8 & 21 & 13.6 & 10 & 6.5 & 15 & 9.7 & 110 & 76.4 \\
\hline ECRAF & 131 & 21.6 & 22 & 3.6 & 246 & 40.5 & 79 & 13.0 & 39 & 6.4 & 41 & 6.8 & 49 & 8.1 & 438 & 77.6 \\
\hline
\end{tabular}

Total number of SE positive alleles was 607 . A total of 267 and 170 subjects carried one and two SE positive alleles respectively.

Table 3 Within-family concordance for demographic and clinical characteristics

\begin{tabular}{llllll}
\hline & $\begin{array}{l}\text { Difference in } \\
\text { years (mean } \\
(S D))\end{array}$ & $\begin{array}{l}\text { Intraclass } \\
\text { correlation } \\
\text { coeffcient }\end{array}$ & $\begin{array}{l}\text { Concordant } \\
\text { pairs (\%) }\end{array}$ & $\kappa$ Value & p Value \\
\hline Age at onset & $10(8)$ & 0.49 & & & NS \\
Calendar year at onset & $10(9)$ & 0.19 & & & NS \\
Sex & & & 70 & 0.12 & NS \\
Rheumatoid factor & & 75 & 0.22 & NS \\
Erosive disease & & 68 & 0.17 & NS \\
Nodules & & 66 & 0.18 & NS \\
Subjective Sjögren's syndrome & & 90 & 0.12 & NS \\
Other extra-articular features & & & & & \\
\hline
\end{tabular}

To assess the concordance within families, disease characteristics between affected siblings were compared. Differences in age at onset (mean (SD) 10 (8) years) and in calendar year of disease onset (mean (SD) 10 (9) years) between sibs were large (intraclass correlation coefficient <0.5). The concordance for categorical variables such as sex, RF, erosive disease, nodules, Sjögren's syndrome, and other extra-articular features was also poor (table 3).

\section{Discussion}

This study describes a large set of European white ASP families collected by the ECRAF for replication studies. The latter are needed to confirm our initial findings which suggested that besides class II HLA genes, at least 10 different genetic regions may be linked to susceptibility to RA. ${ }^{14}$ The relative risk of RA among first degree relatives is barely increased compared with that of the general population, ${ }^{19}$ and familial aggregation of RA is relatively rare. ${ }^{212}{ }^{19-21}$ Collection of such a large family set therefore requires international efforts. These offer the opportunity to assess clinical and immunogenetic aspects of the disease in different countries.

Our results show that there is a considerable heterogeneity of RA across Europe. With the exception of age at onset, sex, and RF status, all clinical and radiological variables studied and the results from HLA typing showed a large diversity between European countries. Despite this diversity, we did not see any clear cut gradient in disease severity from northern to southern Europe. Our results, therefore, do not sustain the notion of a mild phenotype of RA in Mediterranean countries ${ }^{22}{ }_{23}$ compared with a more severe one in northern Europe, ${ }^{24}$ though it is possible that our family collection was not big enough to identify this difference.

Phenotypic heterogeneity may, to a certain extent, be explained by genetic factors, including HLA and SE. We found a higher prevalence of SE and double SE alleles in northern European countries. HLA-DRB ${ }^{\star} 0401$ was the most prevalent allele overall, except for Italy, and DRB $1^{\star} 04$ alleles were highly represented in the Netherlands and Belgium. Differences in SE encoding alleles may be relevant as these are not equivalent in prognostic terms. Severe disease has been associated with $\mathrm{SE}^{9}$, a double SE allele, ${ }^{625}{ }^{26}$ and with certain DR4 alleles or their combinations, ${ }^{725-28}$ whereas DR1 may be associated with a milder disease course. ${ }^{28} 29$ From the above mentioned data, it might be expected that RA should be mild in populations with a high prevalence of DR1 and a low prevalence of DR4 alleles, such as Italy, Spain, and Portugal, and more severe in Belgium and the Netherlands, where DR4 is most common. Our results do not support this hypothesis.

The concordance in disease characteristics within affected members of the same family was also studied. This allows some discernment between relative contributions of genes and environment to disease susceptibility. Disease onset tends to occur at a similar age if genetic factors have a major role, but it clusters around the same calendar year if common environmental factors are important. Age, calendar year of onset, and all other clinical and radiological characteristics assessed differed considerably within affected sib pairs in this and previous studies. ${ }^{30}{ }^{31}$ This emphasises the heterogeneity of the disease even within the same family and may point to a limited role of genetic factors in the susceptibility for RA.

The findings in this study are derived from patients with familial RA and it has been proposed that familial disease may be associated with a more severe disease course. ${ }^{12}$ Recent large cross sectional ${ }^{232} 33$ and longitudinal studies ${ }^{34}$ in European countries show no relevant differences between familial and sporadic RA, except for the sibship size. ${ }^{234}$ Our findings can therefore be extrapolated to sporadic RA.

Taken together, this study describes the clinical and immunogenetic characteristics of RA in a large set of European families collected by the ECRAF for replication studies on new potential RA loci. Our results show that RA is a heterogeneous disease, not only across Europe but even within affected members of the same family. No evidence for a north to south gradient in disease severity was seen in Europe.

We are indebted to the families and clinicians who participated in the study. The authors thank J Weissenbach and R Madero for their contribution to this study. 
Supported by: The European Union (Biomed 2 programme), ARP (Association de Recherche sur la Polyarthrite), AP-HP (Assistance Publique-Hopitaux de Paris), SFR (Societe Francaise de Rhumatologie).

\section{Appendix: Members of the European Consortium on Rheumatoid Arthritis Families}

T Bardin, D Charron, $\mathrm{F}$ Cornélis (coordinator), S Fauré, D Kuntz, M Martinez, JF Prud'homme, J Weissenbach (France); R Westhovens, J Dequeker (Belgium); A Balsa, D Pascual Salcedo (Spain); P Migliorini, S Bombardieri (Italy); M Spyropoulou, C Stravopoulos (Greece); P Barrera, LBA van de Putte (The Netherlands); H Alves, A Lopes-Vaz (Portugal)

1 Ollier WE, MacGregor A. Genetic epidemiology of rheumatoid disease. Br Med Bull 1995;51:267-85.

2 Barrera P, Radstake TR, Albers JM, van Riel PL, van de Barrera P, Radstake TR, Albers JM, van Riel PL, van de
Putte LB. Familial aggregation of rheumatoid arthritis in Putte LB. Familial aggregation of rheumatoid arthritis in the Netherlands: a cross-sectional hospital-based survey.
For the European Consortium on Rheumatoid Arthritis For the European Consortium on Rheumatoid Ar
Families (ECRAF). Rheumatology 1999;38:415-22.

3 Silman AJ, MacGregor AJ, Thomson W, Holligan S, Carthy D, Farhan A, et al. Twin concordance rates for rheumatoid arthritis: results from a nationwide study. $\mathrm{Br} \mathrm{J}$ Rheumatol 1993;32:903-7.

4 Gregersen PK, Silver J, Winchester RJ. The shared epitope hypothesis. An approach to understanding the molecular genetics of susceptibility to rheumatoid arthritis. Arthritis Rheum 1987;30:1205-13.

5 Ollier W, Thomson W. Population genetics of rheumatoid arthritis. Rheum Dis Clin North Am 1992;18:741-59.

6 Wordsworth P, Pile KD, Buckely JD, Lanchbury JS, Ollier $\mathrm{B}$, Lathrop $\mathrm{M}$, et al. HLA heterozygosity contributes to susceptibility to rheumatoid arthritis. Am J Hum Genet 1992;51:585-91.

7 van Zeben D, Hazes JM, Zwinderman AH, Cats A Schreuder GM, D'Amaro J, et al. Association of HLA-DR4
with a more progressive disease course in patients with with a more progressive disease course in patients with rheumatoid arthritis. Result
Rheum 1991;34:822-30.

8 Awad J, Ollier W, Cutbush S, Papasteriadis C, Gupta A, Carthy D, et al. Heterogeneity of HLA-DR4 in Greeks including a unique DR4-DQw2 association. Tissue Antigens 1990;35:40-4

9 Boki KA, Drosos AA, Tzioufas AG, Lanchbury JS, Panayi GS, Moutsopoulos HM. Examination of HLA-DR4 as a severity marker for rheumatoid arthritis in Greek patients. Ann Rheum Dis 1993;52:517-19.

10 Sanchez B, Moreno I, Magarino R, Garzon M, Gonzalez MF, Garcia A, et al. HLA-DRw10 confers the highest susceptibility to rheumatoid arthritis in a Spanish population. Tissue Antigens 1990;36:174-6.

11 Yelamos J, Garcia Lozano JR, Moreno I, Aguilera I, Gonzalez MF, Garcia A, et al. Association of HLA-DR4Dw15 (DRB $\left.1^{\star} 0405\right)$ and DR10 with rheumatoid arthritis in a Spanish population. Arthritis Rheum 1993;36:811-14.

12 Deighton CM, Walker DJ, Griffith ID, Roberts DF. The contribution of HLA to rheumatoid arthritis. Clin Genet contribution of

13 Wordsworth P. Genes and arthritis. Br Med Bull 1995;51: 249-66.

14 Cornélis F, Fauré S, Martinez M, Prud'homme JF, Fritz P, Dib C, et al. New susceptibility locus for rheumatoid arthritis suggested by a genome-wide linkage study. Proc Natl Acad Sci USA 1998;95:10746-50.
15 Shiozawa S, Hayashi S, Tsukamoto Y, Goko H, Kawasaki $\mathrm{H}$, Wada $\mathrm{T}$, et al. Identification of the gene loci that predispose to rheumatoid arthritis. Int Immunol 1998;10: 1891-5.

16 Hardwick LJ, Walsh S, Butcher S, Nicod A, Shatford J, Bell $\mathrm{J}$, et al. Genetic mapping of susceptibility loci in the genes involved in rheumatoid arthritis. J Rheumatol 1997;24: 197-8.

17 Ollier W, Worthington J. Small fish in a big pond. Br J Rheumatol 1997;36:931-2.

18 Arnett FC, Edworthy SM, Bloch DA, McShane DJ, Fries $\mathrm{JF}$, Cooper NS, et al. The American Rheumatism Association 1987 revised criteria for the classification of rheumatoid arthritis. Arthritis Rheum 1988;31:315-24.

19 Jones MA, Silman AJ, Whiting S, Barrett EM, Symmons DP. Occurrence of rheumatoid arthritis is not increased in the first degree relatives of a population based inception cohort of inflammatory polyarthritis. Ann Rheum Dis 1996;55:89-93.

20 Deighton CM, Wentzel J, Cavanagh G, Roberts DF, Walker DJ. Contribution of inherited factors to rheumatoid arthritis. Ann Rheum Dis 1992;51:182-5.

21 Wolfe F, Kleinheksel SM, Khan MA. Prevalence of familial occurrence in patients with rheumatoid arthritis. $\mathrm{Br} \mathrm{J}$ Rheumatol 1988;27(suppl 2):150-2.

22 Drosos AA, Lanchbury JS, Panayi GS, Moutsopoulos HM. Rheumatoid arthritis in Greek and British patients. A comparative clinical, radiologic, and serologic study [see comments]. Arthritis Rheum 1992;35:745-8.

23 Ronda E, Ruiz MT, Pascual E, Gibson T. Differences between Spanish and British patients in the severity of rheumatoid arthritis: comment on the article by Drosos $e t$ al [letter]. Arthritis Rheum 1994;37:147-8.

24 Hameed K, Gibson T. A comparison of the prevalence of rheumatoid arthritis and other rheumatic diseases amongst Pakistanis living in England and Pakistan. Br J Rheumatol 1997;36:781-5.

25 Nepom GT, Nepom BS. Prediction of susceptibility to rheumatoid arthritis by human leukocyte antigen genotyping. Rheum Dis Clin North Am 1992;18:785-92.

26 Weyand CM, Xie C, Goronzy JJ. Homozygosity for the HLA-DRB1 allele selects for extraarticular manifestations in rheumatoid arthritis. J Clin Invest 1992;89:2033-9.

27 McCusker CT, Reid B, Green D, Gladman DD, Buchanan WW, Singal DP. HLA-D region antigens in patients with rheumatoid arthritis. Arthritis Rheum 1991;34:192-7.

28 Singal DP, Green D, Reid B, Gladman DD, Buchanan WW. HLA-D region genes and rheumatoid arthritis (RA): importance of DR and DQ genes in conferring susceptibilimportance of DR and DQ genes in confer

29 Wakitani S, Murata N, Toda Y, Ogawa R, Kaneshige T, Nishimura $Y$, et al. The relationship between HLA-DRB1 alleles and disease subsets of rheumatoid arthritis in Japanese. Br J Rheumatol 1997;36:630-6.

30 Sanders PA, Grennan DM. Age and year of onset differences in siblings with rheumatoid arthritis. Br J Rheumatol 1990;29:128-30.

31 Silman AJ, Ollier WE, Currey HL. Failure to find disease similarity in sibling pairs with rheumatoid arthritis. Ann Rheum Dis 1987;46:135-8.

32 Deighton CM, Walker DJ. What factors distinguish probands from multicase rheumatoid arthritis same sex sibships from sporadic disease? J Rheumatol 1992;19:237-41.

33 Wolfe F, Kleinheksel SM, Khan MA. Familial vs sporadic rheumatoid arthritis: a comparison of the demographic and clinical characteristics of 956 patients. J Rheumatol 1988:15:400-4.

34 Radstake TR, Barrera P, Albers JM, Swinkels HL, van de Putte LB, van Riel PL. Familial versus sporadic rheumatoid arthritis. A prospective study in an early RA inception cohort. Rheumatology (in press). 